\title{
KEBEBASAN BEREKSPRESI DI ERA DEMOKRASI: CATATAN PENEGAKAN HAK ASASI MANUSIA
}

\author{
Della Luysky Selian \\ Mahasiswa Fakultas Hukum, Universitas \\ Negeri Semarang \\ Surel: dellaluysky27@yahoo.com
}

\author{
Cairin Melina \\ Mahasiswa Fakultas Hukum, Universitas \\ Negeri Semarang \\ Surel: cairinmelina@gmail.com
}

\begin{abstract}
ABSTRAK
Sejak digulirkannya reformasi tahun 1998, wacana dan gerakan demokrasi terjadi secara massif dan luas di Indonesia. Hasil penelitian UNESCO menyatakan bahwa mungkin untuk pertama kali dalam sejarah, demokrasi dinyatakan sebagai nama yang paling baik dan wajar untuk semua sistem organisasi politik dan sosial yang diperjuangkan oleh para pendukungnya yang berpengaruh. Tulisan ini mencoba melihat bagaimana pemenuhan dan perlindungan terhadap kebebasan berekspresi di Indonesia dan kaitannya dengan Hak Asasi
\end{abstract}

RIWAYAT ARTIKEL

Article History

Diterima 21 Maret 2017

Dipublikasi 20 November 2018

\section{KATA KUNCI}

Keywords

Demokrasi, Kebebasan Berekspresi,

Hak Asasi Manusia (HAM)

HOW TO CITE (saran perujukan):

Selian, D.L., \& Melina, C. (2018). "Kebebasan Berekspresi di Era Demokrasi: Catatan Penegakan Hak Asasi Manusia", Lex Scientia Law Review. Volume 2 No. 2, November, hlm. 185-194.

\section{PENDAHULUAN}

Kebebasan berekspresi merupakan hak setiap individu sejak dilahirkan yang telah dijamin secara konstitusi. Negara Indonesia sebagai negara hukum dan demokratis berwenang untuk mengatur dan melindungi pelaksanaannya. Kebebasan berpikir dan mengeluarkan pendapat diatur dalam perubahan keempat Undang-Undang Dasar 1945 pasal 28 E ayat (3) setiap orang berhak atas kebebasan berserikat, berkumpul, dan mengeluarkan pendapat. Termasuk kebebasan 
berekspresi yang merupakan hak yang paling mendasar dalam kehidupan bernegara. Indonesia sebagai negara hukum tentu memiliki sejumlah peraturan yang melindungi hak-hak asasi manusia. Salah satu haknya ialah hak untuk kebebasan berekspresi yang dimiliki oleh setiap masyarakat Indonesia tanpa memandang suku, ras dan agama. Kebebasan berekspresi dapat dilakukan dalam berbagai bentuk. Misalnya dalam bentuk tulisan, buku, diskusi, atau dalam kegiatan pers. Semakin dewasa suatu bangsa maka kebebasan berekspresi dan berpendapat akan semakin dihormati.

Keberadaan Hak Asasi Manusia dalam konsepsi negara hukum terkait dengan pengaturan Hak Asasi Manusia oleh negara bukan berarti telah terjadi pengekangan oleh negara namun dalam konsepsinya adalah pengaturan oleh negara. Dalam suatu sisi Hak Asasi memiliki sifat dasar yang membatasi kekuasaan pemerintahan, namun sebaliknya pada sisi lain pemerintah diberi wewenang untuk membatasi hak-hak dasar sesuai dengan fungsi pengendalian (Sturing). Jadi walaupun hak-hak dasar itu mengandung sifat yang membatasi kekuasaan pemerintah, pembatasan tersebut tidak berarti mematikan kekuasaan pemerintah yang dasarnya berisi wewenang untuk mengendalikan kehidupan masyarakat. Salah satu hak dasar warga negara adalah hak demokrasi dan kebebasan atas penyelenggaraan, pemenuhan, dan penggunaan hak demokrasi itu sendiri. Hak tersebut merupakan bagian yang penting dalam perjalanan kebangsaan memngingat bahwa upaya demokratisasi yang berujung pada kebebasan demokrasi tersebut dari waktu ke waktu yang kian terus mengalami perkembangan.

Sejak digulirkannya reformasi tahun 1998, wacana dan gerakan demokrasi terjadi secara massif dan luas di Indonesia. Hasil penelitian menyatakan "mungkin untuk pertama kali dalam sejarah, demokrasi dinyatakan sebagai nama yang paling baik dan wajar untuk semua sistem organisasi politik dan sosial yang diperjuangkan oleh para pendukungnya yang berpengaruh"(UNESCO 1949)."Keyakinan bahwa kehendak rakyat adalah dasar utama kewenangan pemerintah menjadi basis bagi tegak kokohnya sistem politik demokrasi. Awal abad ini pun kita akan terus menyaksikan gelombang aneksasi paham demokrasi mewabah ke seluruh negara berbarengan dengan isu-isu global lainnya seperti hak asasi manusia, keadilan, masalah gender, dan persoalan lingkungan hidup. Pada saat ini hampir semua negara mengaku bahwa sistem pemerintahannya adalah demokrasi. Hal itu menunjukkan bahwa rakyat diletakkan pada posisi penting walaupun secara operasional implikasinya diberbagai negara tidak selalu sama. Tidak ada negara yang ingin dikatakan sebagai negara yang tidak demokratis atau negara otoriter.

\section{Rumusan Masalah}

1. Bagaimana hubungan HAM dalam sistem Politik Demokratis?

2. Bagaimana Prospek Demokratisasi di Indonesia?

3. Bagaimana kebebasan berekspresi dalam perspektif Hak Asasi Manusia?

4. Apakah Kebebasan Berekspresi Dalam Hak Asasi Manusia Dapat Dibatasi?

https://journal.unnes.ac.id/sju/index.php/Islr/

Copyrights (C) 2018. UKM Lex Scientia, Fakultas Hukum Universitas Negeri Semarang 


\section{Metode Penulisan}

Penulisan ini menggunakan metode qualitative research. Dalam Pengumpulan data, data-data dalam penelitian ini penulis menggunakan studi kepustkaan (Library Research), dengan merujuk kepada, buku-buku, jurnal atau artikel. Dalam pengumpulan data-data tersebut penulis lebih mengacu kepada datadata dari buku-buku dan jurnal.

\section{PEMBAHASAN}

\section{A. HAM dalam Sistem Politik Demokratis}

Dalam sistem politik demokratis, watak hukum yang dihasilkan bersifat responsif dan akomodatif. Substansi hukum yang tertuang di dalam beragam peraturan perundangan yang ada menghormati dan menjunjung tinggi hak asasi manusia. HAM menjadi salah satu ukuran penegakan hukum. Dalam sistem tersebut terjalin komunikasi serasi antara opini publik lewat wakil-wakilnya, juga media massa, agamawan, cendekiawan, dan LSM dengan pemerintah. Semua warga negara mempunyai kedudukaan yang sama di depan hukum. Penguasa/ Pemerintah di dalam menjalankan roda pemerintahannya leawat keputusan dan kebijakan yang ditempuh, memiliki kekuasaan, kewenangan, kekuatan, serta fasilitas yang dipakai sebagai alat/sarana, baik dalam menjalankan tugas maupun menyelesaikan konflik yang ada. Politik hukum yang dituangkan di dalam undangundang dasar suatu negara merupakan pedoman utama serta pilihan yang harus dilaksanakan oleh para pejabat negara. (Effendi, 2014:63)

Demokrasi mengalami perluasan jika membawa perbaikan kualitatif terhadap kesejahteraan rakyat, yang meningkatkan kepuasan rakyat pada demokrasi. Indonesia masuk kategori flawed demokrasi (cacat demokrasi), antara lain dengan pemilu yang tidak bersih, pemerintahan yang korup dan ingkar janijanji pemilu, serta keterancaman pluralisme. Kajian demokrasi dalam kepustakaan ilmu politik pada garis besarnya dapat dikelompokkan dalam dua sudut pandang, yaitu kajian tentang demokrasi secara normatif melalui pengelaborasian gagasangagasan, ide-ide yang bersifat abstraksi tentang hakekat demokrasi itu sendiri. Sedangkan di lain pihak, konsep demokrasi dapat pula ditelaah dari segi prosedural, yaitu bagaimana praktek demokrasi di suatu negara. Sebelum melangkah lebih jauh dalam memahami demokrasi, perlu disadari bahwa sikap ethnosentrisme dalam konteks ini harus dihindari. Sebab sikap ini menjadikan kita tidak mampu menatap diri sendiri secara objektif. (Sari, 2003)

Pemaknaan terhadap demokrasi menuntut kemauan setiap orang untuk dapat menghindari sikap etnosentrisme. Demokrasi memberikan peluang bagi setiap orang untuk menikmati kebebasan yang dimilikinya secara proporsional karena kebebasan yang dimilikinya dibatasi oleh kebebasan orang lain. Perwujudan demokrasi dalam tataran empiris bukanlah suatu hal yang mudah karena memerlukan waktu yang panjang serta pelaksanaan dari berbagai hal yang paradoks dalam waktu bersamaan. Hak dan kebebasan politik melahirkan ciri kedua atau dimensi kedua dari demokrasi, yaitu pluralisme politik. Karena itu ada yang mengatakan kalau tidak dijamin pluralisme, tidak ada demokrasi. (Surbakti, 2003:1-6) 


\section{B. Prospek Demokratisasi di Indonesia}

Demokratisasi adalah penerapan kaidah-kaidah atau prinsip-prinsip demokrasi pada setiap kegiatan politik kenegaraan. Tujuanya adalah terbentuknya kehidupan politik yang bercirikan demokrasi. Demokratissasi merujuk pada proses perubahan menuju pada sistem pemerintahan yang lebih demokratis. Demokratisasi juga berarti proses menegakkan nilai-nilai demokrasi sehingga sistem politik demokratis dapat terbentuk secara bertahap. Nilai-nilai demokrasi dianggap baik dan positif bagi setiap warga. Setiap warga menginginkan tegaknya demokrasi di negaranya. (Winarno, 2009:97)

Sejak kejatuhan Soeharto telah terjadi perubahan-perubahan yang berarti dalam kehidupan politik di Indonesia. Beberapa perubahan itu membuka peluang bagi terwujudnya transisi menuju demokrasi walaupun tidak ada garansi bahwa transisi yang dimulai secara kongkrit sejak terbentuknya pemerintahan baru pasca pemilu 1999 benar-benar akan memberikan kondisi yang kondusif bagi terkonsolidasikannya demokrasi di Indonesia. Disamping itu perlu disadari bahwa reformasi yang bergulir masih diwarnai oleh berbagai distorsi dimana orang berpikir dan melangkah tanpa kendali nilai dan tanpa sisa kepercayaan pada institusi sosial yang tersedia (Sari, 2003). Pratransisi berlangsung sebelum kejatuhan rezim yang berkuasa. Biasanya dalam tahapan ini terjadi krisis ekonomi dan politik yang sulit dikelola, perlawanan yang kuat dari massa, perpecahan di tubuh elit, serta kuatnya tuntutan akan perubahan terhadap sistem politik. Sementara itu liberalisasi politik terjadi setelah pergantian rezim yang diiringi oleh meluasnya hak-hak politik rakyat.

Disamping itu pada tahapan ini juga terjadi ungovernability, ledakan partisipasi politik serta terbentuknya ketidakpastian dalam banyak hal. Selanjutnya tahapan ketiga yaitu transisi. Tahap ini diawali oleh terbentuknya pemerintahan baru dengan legitimasi yang kuat. Pemerintahan transisi harus mampu melakukan penataan terhadap perangkat keras dan perangkat lunak dari sistem politik. Perangkat keras meliputi : (1) pergantian pelaku ; (2) tumbuhnya institusi baru ; (3) perubahan dan pergantian aturan ; serta (4) perubahan dan pergantian mekanisme kerja politik, ekonomi dan sosial. Sedangkan perangkat lunak terkait dengan paradigma atau cara berpikir, pola perilaku, tabiat dan kebudayaan dalam masyarakat. Keberhasilan pada tahap ini akan mengantarkan pada tahapan konsolidasi demokrasi. Konsolidasi demokrasi ditandai oleh tertatanya perangkat keras sistem politik secara relatif baik dan diiringi oleh terselenggaranya pemilu secara demokratis dengan menghasilkan pemerintahan yang memiliki legitimasi makin kukuh. Konsolidasi demokrasi memerlukan waktu yang relatif lebih lama. Keempat tahapan ini selanjutnya akan kita gunakan dalam mencermati prospek demokrasi di Indonesia.

\section{Kebebasan Berekspresi Dalam Perspektif Hak Asasi Manusia}

Hak Asasi Manusia merupakan hak dasar yang secara kodrati melekat padadiri manusia, hak asasi manusia bersifat universal dan langgeng, sehingga harus dihormati, dilindungi, dan dipenuhi serta tidak boleh diabaikan, dikurangi atau dirampas oleh siapapun. Tugas penghormatan, perlindungan dan pemenuhan HAM selain kewajiban dan tanggung jawab pemerintah, dibutuhkan juga peran 
dan partisipasi dari masyarakat(Rahmanto, 2016:46). Diskursus demokrasi di Indonesia sebenarnya telah melewati sejarah yang panjang. Usaha untuk mewujudkan pemerntahan demokratis dapat dilihat dari rumusan model demkrasi di Indonesia di dua zaman pemerintahan Indonesia, yakni Orde Lama dan Orde Baru. Era Soekarno dikenalkan model demokrasi terpimpin, sedang era Soeharto dimunculkan Demokrasi Pancasila. Namun, alih-alih terbentuk suatu pemerintahan yang demokratis, model demokrati yang ditawarkan di dua rezim tersebut malah memunculkan pemerintah otoritarian, yang membelenggu kebebasan politik warganya (Marzuki, 2011:49). Di awal era reformasi di Indonesia penegakan HAM memang menjadi tuntutan utama bagi masyarakat. Masyarakat menuntut dan menghendaki adanya kesempatan untuk dapat menyampaikan pendapat dengan baik melalui tulisan ataupun lisan, dapat berpartisapasi dalam pemerintahan dan kemudian dapat berorganisasi. Dengan lahirnya tuntutan dari masyarakat tersebut maka dapat dikatakan bahwa pada masa Orde Baru kebebasan berserikat, berkumpul, dan mengemukakan pendapat memang terbelenggu oleh kekuasaan pemerintah.

Kebebasan berekspresi merupakan elemen yang penting dalam demokrasi, sebelum disahkannya Universal of Human Rights dalam sidang pertamanya. Majelis Umum PBB melalui Resolusi Nomor 59 terlebih dahulu telah menyatakan bahwa "hak atas informasi merupakan hak asasi manusia fundamental...standar dari semua kebebasan dinyatakan 'suci' oleh PBB". Kebebasan berekspresi merupakan menjadi salah satu elemen yang penting dalam berlangsungnya demokrasi serta partisipasi publik dalam melaksanakan haknya secara efektif baik dalam hal partisipasinya dalam pengambilan sebuah kebijakan publik atau dalam hal pemungutan suara. Apabila masyarakat tidak memiliki kebebasan untuk mengemukakan pendapatnya atau menyalurkan aspirasinya maka dapat dikatakan bahwa proses demokrasi dalam suatu Negara tidak berjalan baik serta dapat menimbulkan suatu pemerintahan yang otoriter.

Dengan terbentuknya Universal Declaration of Human Rights (UDHR) yang diawali dengan terbentuknya Perserikatan Bangsa-Bangsa (PBB) pada tahun 1945, tujuan utama dari pembentukan PBB ialah untuk memelihara perdamaian dan keamanan dunia. Dalam Universal Declaration of Human Rights telah diuraikan pengertian bersama dari semua rakyat yang ada di dunia mengenai hakhak yang tidak dapat dicabut ataupun dilanggar yang dimiliki oleh setiap manusia. Isi dari Deklarasi tersebut ialah pengakuan atas martabat alamian dan hak-hak yang sama dan mutlak dari semua anggota keluarga manusia adalah dasar kemerdekaan, keadilan dan perdamaian di dunia. Hak tersebut antara lain ialah hak untuk hidup, hak untuk menyampaikan pendapat, hak untuk persamaan di depan hukum, hak mendapatkan penghidupan yang layak, dan sebagainya.

https://journal.unnes.ac.id/sju/index.php/lsIr/

Copyrights (c) 2018. UKM Lex Scientia, Fakultas Hukum Universitas Negeri Semarang 
Dalam hal kebebasan berekspresi untuk mengemukakan pendapat, didalam pasal Deklarasi Hak Asasi Manusia ialah terdapat rumusan yang menyatakan bahwa:

"Setiap orang berhak atas kebebasan mempunyai dan mengeluarkan pendapat; dalam hal ini termasuk kebebasan menganut pendapat tanpa mendapat gangguan, dan untuk mencari, menerima dan menyampaikan keterangan keterangan dan pendapat dengan cara apapun dan dengan baik memandang batas batas."

Dari definisi pasal diatas menunjukkan bahwa pengakuan secara internasional bahwa kebebasan berpendapay dan kebebasan merupakan satu standar dari hak asasi manusia yang sangat diakui secara luas di forum internasional. Kebebasan berpendapat merupakan kebebasan yang merupakan hak asasi manusia yang perlu dijamin dan dijunjung tinggi oleh semua orang. Kebebasan berpendapat merupakan bagian dari hak asasi manusia, yang kebebasannya merupakan perwujudan dari ketundukan berbicara secara lisan atau tertulis di setiap media tanpa ada halangan dari setiap partai. Kebebasan mengemukakan pendapat merupakan bagian yang mendasar dari hak asasi. Selanjutnya dalam pasal 20 Deklarasi Hak Asasi Manusia menyatakan bahwa:

1. Setiap orang mempunyai hak atas kebebsan berkumpul dan berserikat tanpa kekerasan.

2. Tidak seorang pun boleh dipaksa untuk memasuki suatu perkumpulan

Berkaitan dengan kebebasan berpendapat, terdapat konvennan yang sesuai yaitu International Convenant on Civil and Political Rights (ICCPR). Konvenan ini mengatur tentang hak-hak demokrasi yang esensial. Kebebasan individu untuk meningkatkan kualitas hidupnya, partisipasi dalam politik dan kebebasan untuk berekspresi jelas sangat berkaitan dengan demokrasi.

Jaminan akan kebebasan dalam berpendapat, berorganisasi dan ikut berpartisipasi dalam pemerintahan sebenarnya sudah diatur dan dijamin dalam UUD 1945. Sehingga perlindungan terhadap HAM dalam konstitusi hanya dipandang sebagai nilai nominal untuk melindungi HAM. Maka dalam amandemen UUD 1945 dengan keinginan untuk memberikan perlindungan terhadap HAM terhadap warga negara. Perlindungan HAM secara terperincu dijabarkan dalam Pasal 28 yaitu dalam Pasal 28A hingga Pasal 28J UUD 1945, serta tersebar dalam ketentuan pasal lainnya. Demikian halnya dengan aturan terkait dengan kebebasan berpendapat dalam pasal 28 yang selanjutnya diatur lebih rinci lagi dalam pasal 28 F UUD 1945 menyatakan bahwa "Setiap orang berhak untuk berkomunikasi dan memperoleh informasi untuk mengembangkan pribadi dan lingkungan sosialnya, serta berhak untuk untuk mencari, memperoleh, memiliki, menyimpan, mengolah, dan menyampaikan informasi dengan menggunakan segala jenis saluran yang tersedia". Dalam Undang-Undang Nomor 39 Tahun 1999 tentang Hak Asasi Manusia Pasal 4 Ayat (2) menyatakan bahwa "Setiap orang berhak untuk mencari, memperoleh, memiliki, menyimpan, mengolah, dan menyampaikan informasi dengan menggunakan segala jenis sarana yang tersedia". Selain itu dalam dalam

https://journal.unnes.ac.id/sju/index.php/lsIr/

Copyrights (c) 2018. UKM Lex Scientia, Fakultas Hukum Universitas Negeri Semarang 
Konvenan Internasional tentang Hak Sipil dan Politik yang terdapat dalam pasal 9 ayat (2) juga menyatakan bahwa "setiap orang berhak atas kebebasam untuk mencari, menerima dan memberikan informasi dan ide/gagasan apapun, terlepas dari pembatasanpembatasan, baik secara lisan, tulisan, cetakan, dalam bentuk karya seni atau melalui media lain sesuai dengan pilihannya."

Pada pasal tersebut negara menjamin kebebasan setiap individu baik itu secara lisan maupun dalam bentuk tulisan untuk menyampaikan pendapatnya. Dari ketentuan tersebut merupakan bentuk adobsi terhadap perlindungan HAM yang sebagaimana diatur dalam Pasal 19 Deklarasi Universal Hak Asasi Manusia (DUHAM) PBB, yang selanjutnya diatur dalam International Convenanat on Civil and Political Right (ICCPR).

Kebebasan masyarakat dalam berekspresi untuk mengemukakan pendapatnya merupakan hak dan tanggung jawab dari negara demokrasi. Memilih dan dipilih merupakan hak sipil politik. Sebagai hak, ia menghendaki jaminan kebebasan untuk menggunakan atau tidak menggunakannya. Memilih untuk memilih atau memilih untuk tidak memilih adalah pilihan dan pilihan adalah hak (Cahyo, 2015).

Dalam suatu pemerintahan yang demokratis masyarakat diberi kesempatan untuk menilai kinerja pemerintah. Dalam penilaian dan kontrol itulah masyarakat memerlukan semua informasi tentang pemerintahan. Kebebasan berekspresi memiliki dimensi politik, bahwa kebebasan berekpresi dianggap sebagai elemen yang mendasar bagi keikutsertaan warga dalam kehidupan politik serta mendorong gagasan kritis. Hubungan kebebasan berekspresi dengan demokrasi yang kemudian diakui dalam hukum internasional hak asasi manusia yang menyatakan bahwa kebebasan berekspresi menjadi prasyarat dalam terwujudnya prinsip transparansi dan akuntabilitas yang pada akhirnya sangat esensial bagi pemajuan dan perlindungan hak asasi manusia. Kebebasan berekspresi kemudian juga digunakan sebagai pintu bagi dinikmainya kebebasan berkumpul, berserikat dan pelaksanaan hak untuk memilih.

Kebebasan berekspresi sebagai hak liberal menjadi jembatan dari dua arah dimensi hak sipil (hak bebas dari intervensi negara) dan hak politik (hak untuk menentukan negara). Kebebasan berekspresi menjadi suati penanda dari suatu tatanan politik yang demokratis. Selain menjadi hak liberal, kebebasan berekspresi juga menjadi hak individual untuk membentuk, membangun, dan mengemukakan pendapat (opini)nya sendiri dari indoktrinasi eksternal dan hak ini juga sebagai benteng dari kebebasan mengungkapkan ide dan gagasan yang dapat diintervensi. Hak ini juga menjadi suatu batu loncatan dari hak-hak lainnya, baik itu hak-hak sipil-politik, maupun hak-hak ekonomim sosial, dan budaya lainnya.

\section{Pembatasan Kebebasan Berekspresi Dalam Hak Asasi Manusia}

Kebebasan berekspresi (dan beropini) merupakan salah satu kategori hak asasi manusia yang utama. Hak ini masuk dalam kategori hak asasi pertama, hak dengan dimensi sipil-poitik. Kategori hak ini misalnya dapat ditemui dalam salah satu dokumen HAM acuan tertua, seperti French Declaration of The Rights of Man and Citizen of 1789 (art. 11). Meskipun hak berekspresi dianggap 'tidak' sefundamental ha katas hidup, hak beragama dan berkeyakinan, hak bebas dari penyiksaan, dan

https://journal.unnes.ac.id/sju/index.php/lsir/

Copyrights (C) 2018. UKM Lex Scientia, Fakultas Hukum Universitas Negeri Semarang 
masih dimungkinkan untuk diderogasi, hak ini selalu menjadi pengawal utama hak-hak dasar manusia. Pertanyaan muncul ketika kebebasan berekspresi digunakan untuk menghasut dan mengorbankan kebencian, atau etnisitas, kebangsaan, asal usul, xenophobia (kebencian terhadap orang asing), dan agama.

Dalam Konvenan Hak-Hak Sipil Politik (International Convenant on Civil and Political Rights/ICCPR) secara eksplisit dijelaskan bahwa dimungkinkannya suatu pembatasan atau pengurangan atas berbagai kategori hak asasi, meskipun hal tersebut dilakukan secara situasional dan bersyarat. Hal ini menunjukkan bahwa perspektif atau instrument HAM membolehkan suatu pelaksanaan pemenuhan HAM dapat dikompromikan dengan urusan lain, seperti terjadinya gangguan keamanan dalam skala besar, mengancam keamanan public, masalah bencana alam dan sebagainya. Sejauh prasyarat tersebut dilaksanakan tetap menjunjung demokrasi dan dilakukan semata-mata demi terwujudnya kesejahteraan sosial.

Konvenan Sipil yang disusun untuk mencari sebuah keseimbangan antara kepentingan 'murni' suatu negara untuk menghadapi penyalahgunaan kekuasaan oleh rezim otoriter dengan melegitimasi situasi bahaya darurat domestiknya. Dalam konvenan sipil ini ketentuan pembatasan hak-hak asasi tertentu dan penerapan kondisi darurat diatur secara khusus pada pasal 4 dan prinsip-prinsip umumnya dilengkapi dengan pasal 5. Dalam pasal 4 Konvenan Sipil menyebutkan bahwa 7 hak-hak asasi yang tidak bisa dikurangi (non-derogable rights). Bukan berarti dalam situasi darurat dapat mengabaikan hak asasi lainnya dan tetap untuk memenuhi kewajiban untuk mematuhi dan memenuhi ketentuan hukum internasional lainnya.

Dari uraian diatas dapat dikatakan bahwa kebebasan berekspresi, menyatakan pendapat yang dinyatakan dalam pasal 19 ICCPR dan hak berorganisasi/berasosiasi (Pasal 21 ICCPR) dapat dijadikan sebagai subjek derogasi (pembatasan atau pengurangan). Subjek dari derogasi sendiri termuat dalam pasal 19, Pasal 20 dan Sub-pasal 19 dan 2. Ketentuan dalam pasal 20 menjadi pagar pembatas kebebasan berekspresi dan menyatakan pendapat. Hal ini sangat relevan untuk mencegah adanya kebebasan berekspresi dalam bentuk tulisan, gambar, atau audio yang didalamnya berisi seruan atau propaganda untuk perang. Selain itu pembatasan dalam kebebasan berekspresi juga dibatasasi dalam hal menyuarakan akan kebencian atas dasar kebangsaan, ras, agama yang merupakan suatu tindakan penghasutan untuk melakukan diskriminasi.

https://journal.unnes.ac.id/sju/index.php/lslr/

Copyrights (c) 2018. UKM Lex Scientia, Fakultas Hukum Universitas Negeri Semarang 


\section{KESIMPULAN}

Dalam sistem politik demokratis, watak hukum yang dihasilkan bersifat responsif dan akomodatif. Substansi hukum yang tertuang di dalam beragam peraturan perundangan yang ada menghormati dan menjunjung tinggi hak asasi manusia. HAM menjadi salah satu ukuran penegakan hukum. Dalam sistem tersebut terjalin komunikasi serasi antara opini publik lewat wakil-wakilnya, juga media massa, agamawan, cendekiawan, dan LSM dengan pemerintah. Semua warga negara mempunyai kedudukaan yang sama di depan hukum. Penguasa/Pemerintah di dalam menjalankan roda pemerintahannya leawat keputusan dan kebijakan yang ditempuh, memiliki kekuasaan, kewenangan, kekuatan, serta fasilitas yang dipakai sebagai alat/sarana, baik dalam menjalankan tugas maupun menyelesaikan konflik yang ada. Politik hukum yang dituangkan di dalam undang-undang dasar suatu negara merupakan pedoman utama serta pilihan yang harus dilaksanakan oleh para pejabat negara.

Demokratisasi adalah penerapan kaidah-kaidah atau prinsip-prinsip demokrasi pada setiap kegiatan politik kenegaraan. Tujuanya adalah terbentuknya kehidupan politik yang bercirikan demokrasi. Demokratissasi merujuk pada proses perubahan menuju pada sistem pemerintahan yang lebih demokratis. Demokratisasi juga berarti proses menegakkan nilai-nilai demokrasi sehingga sistem politik demokratis dapat terbentuk secara bertahap. Kebebasan berekspresi merupakan elemen yang penting dalam demokrasi, sebelum disahkannya Universal of Human Rights dalam sidang pertamanya. Majelis Umum PBB melalui Resolusi Nomor 59 terlebih dahulu telah menyatakan bahwa "hak atas informasi merupakan hak asasi manusia fundamental...standar dari semua kebebasan dinyatakan 'suci' oleh $P B B^{\prime \prime}$. Kebebasan berekspresi merupakan menjadi salah satu elemen yang penting dalam berlangsungnya demokrasi serta partisipasi publik dalam melaksanakan haknya secara efektif baik dalam hal partisipasinya dalam pengambilan sebuah kebijakan publik atau dalam hal pemungutan suara.

Kebebasan berekspresi (dan beropini) merupakan salah satu kategori hak asasi manusia yang utama. Hak ini masuk dalam kategori hak asasi pertama, hak dengan dimensi sipil-poitik. Kategori hak ini misalnya dapat ditemui dalam salah satu dokumen HAM acuan tertua, seperti French Declaration of The Rights of Man and Citizen of 1789 (art. 11). Meskipun hak berekspresi dianggap 'tidak' sefundamental ha katas hidup, hak beragama dan berkeyakinan, hak bebas dari penyiksaan, dan masih dimungkinkan untuk diderogasi, hak ini selalu menjadi pengawal utama hak-hak dasar manusia. Pertanyaan muncul ketika kebebasan berekspresi digunakan untuk menghasut dan mengorbankan kebencian, atau etnisitas, kebangsaan, asal usul, xenophobia (kebencian terhadap orang asing), dan agama. 


\section{DAFTAR PUSTAKA}

Buku

Effendi, M., \& Evandri, T. S. (2014). HAM Dalam Dinamika/Dimensi Hukum, Politik, Ekonomi, Dan Sosial. Bogor: Ghalia Indonesia.

Winarno. (2009). Paradigma Baru Dalam Pendidikan Kewarganegaraan. Jakarta: Grafika Offset.

Marzuki, S. (2011). Tragedi Politik Hukum HAM. Yogyajarta: PUSHAM UII.

Rahayu. (2015). Hukum Hak Asasi Manusia. Semarang : Badan Penerbit Universitas Diponegoro, Cet.III, hlm. 4

\section{Jurnal}

Bayu Dwi Cahyo, Muhammad.(2015)."Tingkat Partisipasi Masyarakat dalam Menggunakan Hak Suara pada Pemilu Legislatif 2014", Pandecta, Vol.10, No.1.

Lukitasari, D. (2013). "Freedom Of Speech In Cyberspace In Human Rights Protection Perspective". International Journal of Busines, Economics and Law, 80.

Rahmanto, T. Y. (2016, Juli 1). "Kebebasan Berekspresi Dalam Perspektif Hak Asasi Manusia: Perlindungan, Permasalahan dan Implementasinya di Provinsi Jawa Barat". Jurnal Hak Asasi Manusia, 46.

Sari, Estika. (2003). "Demokrasi dan Hak Asasi Manusia", Demokrasi, Vol.II, No.1

Surbakti, Ramlan. (April 1999). "Demokrasi dan Hak -Hak Asasi Manusia", Masyarakat Kebudayaan dan Politik, Th XII, No.2, hlm.1-6.

\section{Peraturan Perundang-undangan}

Undang-Undang Dasar Negera Republik Indonesia Tahun 1945

Undang-Undang Nomor 39 Tahun 1999 Tentang Hak Asasi Manusia

Konvenan Internasional tentang Hak-Hak Sipil dan Politik Tahun 1966 